\title{
Experiencing Vulnerability, Abuse and Deception: Why Women in Sylhet City of Bangladesh Enter into Prostitution
}

\author{
Md. Fakhrul Alam, Tulshi Kumar Das* \\ Department of Social Work, Shahjalal University of Science \& Technology, Sylhet-3114, Bangladesh \\ *Corresponding Author: tulshikumardas@gmail.com
}

\begin{abstract}
Sexual activities and sexual behavior are usually restricted within the institution of marriage in Bangladesh. In spite of social and legal restrictions, a significant number of women and girls are involved in prostitution for which they are stigmatized, treated as unchaste and even untouchable, and ultimately rejected by the society. This article is the result of a qualitative study aimed at gaining understanding about multiple factors causing prostitution in Sylhet city of Bangladesh. By following snowball sampling technique, and taking help from the NGO workers, we conducted 53 semi-structured interviews with street- and hotel-based female prostitutes. The findings reveal that no prostitutes had prior idea regarding professional sex work but they had to enter into this profession for many reasons such as financial crisis, poverty, lack of job facilities, deception by lovers, husbands, brokers, desertion, divorce, physical and (or) emotional and sexual abuse. In addition to this, social stigma, gender based discriminatory attitude and outlook of the male dominated society discouraged the women to leave their profession. Overall, our findings reflect the complex interrelationships between both the push and pull factors that generally keep the women and girls entrapped into prostitution in the context of Bangladesh.
\end{abstract}

Keywords Prostitution, Push and Pull Factors, Vulnerability, Abuse, and Deception, Semi-Structured Interviews, Bangladesh

\section{Background}

The institution of prostitution as a profession is widespread throughout the world. It is often called the world's oldest profession (Ditmore, 2006; Kornblum, 2008), and has been legalized in some developed countries, but is often organized and controlled through private enterprises across the globe (Sanders, O'Neill, \& Pitcher, 2009).
Demand and supply of women and girls for prostitution and pornography have been evidently on the increase. The trend is very much found in Bangladesh too as the number of different types of prostitutes have approximately been counted as 100,000 (Aziz, 2003). At the same time, the life and livelihood of women have been significantly influenced due to the impact of globalization, industrialization and urbanization resulting in major structural changes in the society. The root causes of prostitution can be explained by analyzing the very social structure that includes gender inequality, gender based discrimination and exploitation, gender related violence, women's inferior status, changes in social and economic institutions, etc. Therefore, sociological and historical research indicates that the institution of prostitution adapts itself to new societies and new social conditions (Kornblum, 2008).

Bangladesh is a patriarchal society where majority of the people are Muslims. Its social structure, cultural pattern, especially its values, beliefs, tradition, role and status, gender based attitude and practices are highly influenced by patriarchal as well as religious beliefs. In Islam, sexual relationship between male and female outside marriage is described as committing zina (illegal sex, adultery, fornication) which is completely prohibited and publicly punishable (Aziz, 2003; Bishop, 2006; Campo, 2009). Therefore, prostitution is generally disapproved of and hated in Islam. Although religious doctrine of Islam does not approve of prostitution in any circumstances, it exists very much in one way or the other in most Islamic history (Norris, 2006). Despite prostitution is officially disapproved of in many Islamic countries: Pakistan, Afghanistan, and even in the Gulf states, it is widely tolerated and tacitly accepted (Bishop, 2006; Mukherjea, 2006; Norris, 2006; Prostitution, 2014). However, Turkey a predominantly Muslim country and Bangladesh both have legalized the profession of prostitution (Prostitution, 2014). Although Bangladeshi society has been going through multifarious changes, the status of women are still devalued, gender based inequality persists and different forms of violence against women 
continue (Bhuiya, Sharmin, \& Hanifi, 2003; Dalal, Rahman, \& Jansson, 2009; Khan, 2005; Sambisa, Angeles, Lance, Naved, \& Curtis, 2010; Schuler \& Islam, 2008). The existing social system pushes many women and girls to accept prostitution, and simultaneously it stigmatizes them as veshya (whore), impure, patita (fallen), polluted; and they are ultimately rejected by the society (Aziz, 2003; Dummett, 2010; Tahmina \& Moral, 2004). On the contrary, those men who visit the brothels and buy these services are not stigmatized rather tolerated.

Prostitution in Indian sub-continent became institutionalized during the period of British colonial rule, and has been continuing (Kole, 2009; Mukherjea, 2006; Tahmina \& Moral, 2004). Once a woman gets involved in it, she eventually finds herself 'caught up' in the vicious trap of multiple socioeconomic and psychological factors, hardly gets any opportunity to come back because of the societal stigma that awaits her (Biraj, 2012; Tahmina \& Moral, 2004; Valandra, 2007). The prostitutes in Bangladesh like other countries do intend to leave the profession if proper economic rehabilitation can be arranged (Farley \& Barkan, 1998; Rahman, 2001; Tahmina \& Moral, 2004).

The current study has been conducted on 53 women and girls who eventually have taken up the profession of prostitution and have been living and working in and around the Sylhet city of Bangladesh. To explore multiple factors responsible for prostitution, this study has concentrated on the following research questions to examine the contexts of prostitution.

1. How and why women and girls enter or become entrapped in the flesh trade at Sylhet city, Bangladesh?

2. What are the push or pull factors that drive/bring or attract the women into prostitution?

3. Despite experiencing risks, hardships, and blame why they do not leave this profession?

4. What kind of barriers do the women and girls face while planning to leave prostitution?

\section{Review of Literature}

Different studies around the world have identified diverse factors causing female prostitution. Women and girls are often forced into prostitution through kidnapping, abduction and cheating. Tahmina and Moral (2004) show in their study that most of the brothel-based prostitutes in Bangladesh do not accept prostitution by choice rather they are forced-a substantial number of girls are abducted, kidnapped or brought by cheating, and then sold to brothels every year (Islam, 1994; Khan, 2005; Rahman, 2001; Tahmina \& Moral, 2004). Similarly, in a study with 48 female prostitutes from Mumbai, India, it was identified that majority of the prostitutes were sold into prostitution by family members or acquaintances (Karandikar et al., 2011). In Bangladesh, a girl after abduction is generally sold to different brokers, moving from one hand to another in many ways for several times, when she is finally sold to a sardarni (a senior prostitute/madam) of the brothel. In the beginning, a sold girl is kept starved, beaten up and gang-raped to suppress her resistance so that she is forced to take clients. She is further tortured by brutal beating and drug administering, and is being brought to the concerned authorities to manage a license for her to be a prostitute. For this entire exercise, the authorities are allegedly bribed. After a period, a prostituted girl intending to come out of the vicious trap of the brothel finds all its ways blocked, though she breaks up the bondage of sardarni by then (Tahmina \& Moral, 2004). Studies conducted in Bangladesh have found out that cheating of male and female brokers and deception by relatives, husband or stepmother as significant factors that are mostly instrumental to make the women and girls involved into prostitution (Rahman, 1999, 2001; Islam, 1994; Tahmina \& Moral, 2004).

Studies (Islam, 1994; Rahman, 1999, 2001) also show that unmarried women (mainly young girls) are sometimes forced to embrace prostitution when they become completely helpless due to the failure in love affairs. For instances: in some cases, when a girl becomes pregnant because of premarital relationship and the denial of fatherhood of the fetus by her male partner makes the girl helpless; in other cases it is the male partner, who suddenly leaves his girlfriend after knowing the fact of her pregnancy. Again in some cases, a male partner leaves his fiancée after eloping, leaving the girl in a state of frustration and helplessness, which ultimately push her into the profession of prostitution. A number of researchers (Chattopadhyay et al., 1994; Islam, 1994; Karandikar et al., 2011; Kornblum, 2008; Monroe, 2005; Rahman, 1999, 2001; Williamson \& Folaron, 2003) across the world have primarily identified poverty or financial crisis along with unemployment and (or) underemployment as the root causes for prostitution. Similarly, in their study in Mumbai, India Karandikar et al. (2011) identified that death of parent(s) of a girl or the death of the husband has caused her to be in the prostitution. Earlier, Rahman (1999) has found that desertion by husband also pushes some women to enter into prostitution in Bangladesh. Rahman (1999) goes on to reveal that in Bangladesh oppression by husband, mother-in-law and (or) stepmother, in addition to other familial disputes often push some women and girls into prostitution. Besides, widowhood of females has also been identified as one of the factors, which force the widow to be a prostitute in order to survive (Kornblum, 2008). It is ironical to state here that the risk factors such as death of the only earning member, desertions as well as widowhood generally push poor women and girls further into the scourge of poverty, which then sometimes compel them to join prostitution, finding no other better option for their survival.

Previous studies have also reported that some prostitutes working in street and different brothels have very limited educational background, which restricted them from entering into better jobs but forced them to work as prostitutes 
(Chattopadhyay et al., 1994; Rahman, 2001). In similar context, the Anglo-American scholars Kramer and Berg (2003) used a survey data obtained from 309 women working in street-level prostitution in Phoenix, Arizona, and found that women engaged in prostitution had very little education, some of them even could not complete high school.

Likewise, Karandikar et al. (2011) found that some married women in India entered into prostitution only to escape marital abuse. Similarly, in another study conducted in the state of West Bengal, India, Chattopadhyay et al. (1994) had shown that breakdown of family and marital ties or disintegration in family made the poor and illiterate women enter into prostitution for being incapable of supporting the solely dependent family members. Williamson and Folaron (2003) argue that women having poor interaction with conventional society, passing idle time and stuck with family instability are other major determinants for prostitution.

Studies across the globe (Kramer \& Berg, 2003; Ross, Farley, \& Schwartz, 2004; Simons \& Whitbeck, 1991; Surratt, Inciardi, Kurtz, \& Kiley, 2004) confirm that majority of women prostitutes had the experience of physical and sexual abuse in childhood, which was influential in leading them into prostitution. Karandikar et al. (2011) also linked prostitution with the history of childhood sexual abuse. They have explained that the prostitutes resorted to prostitution after being raped, sexually harassed, or inappropriately touched as children, resulting in leaving their respective villages and escaping away from the shame, guilt, or humiliation.

Some of the prostitutes are not able to leave the profession due to different psychological states that keep and force them attached with it. The prostitutes are isolated, suffer from anxiety, depression, and inferiority and from major psychological disorders, which in turn diminish their capacity of thinking freely and wisely that prevent them from being freed from the shackle of prostitution (Farley \& Barkan, 1998; Ross, et al., 2004; Williamson \& Folaron, 2003). Studies also suggest that there are women and girls who enter deliberately into prostitution so that they can earn large sum of money to buy and use drugs (Kornblum, 2008; Young et al., 2000) — that prostitutes become drug addicted and can think of nothing except prostitution (Kornblum, 2008; Ross et al., 2004; Williamson \& Folaron, 2003; Young et al., 2000).

Once a girl involves herself in prostitution, she cannot come out of it due to different socioeconomic and psychological reasons. The prostitutes are stigmatized as fallen or unchaste because of which they always feel that society will not accept them even after quitting prostitution (Kole, 2009; Tahmina \& Moral, 2004). In Bangladesh however, the prostitutes are not allowed to be buried or cremated, rather their dead body is floated down in a river or left to be decomposed on a remote shoal (Hammond, 2008;Tahmina \& Moral, 2004). In her news report, Hammond (2008) further describes that most families stop searching for their kidnapped daughters just after they become aware that their daughters have been sold into the brothels. The tacit stigma that girls from the brothels would invoke shame for their families prevents most families from searching them. Thus, social attitude and gender based discriminatory practices discourage women to leave prostitution. It is found that some prostitutes in Bangladesh take initiatives to depart from prostitution through marriage, however, they fail to receive any pragmatic help from the society (Tahmina \& Moral, 2004; Williamson \& Folaron, 2003). Rather they are exploited economically by their so-called lovers or husbands (Tahmina \& Moral, 2004). In fact, most prostitutes face four primary challenges: emotional work to understand past experiences, struggles with shame, difficulty maintaining intimate and close relationships, and coping with a financially marginal living situation while planning to leave prostitution (Williamson \& Folaron, 2003, p. 272).

\section{Methodology}

The study is an exploratory one, conducted in Sylhet city of Bangladesh with 53 prostitutes aged between 15-44 years. Semi-structured interviews and observation methods were used for this study. Initially, the presence of the prostitutes in different locations of the city and NGO service centers were identified, and subsequently 53 prostitutes were met for semi-structured interviews.

Data was collected taking the help of two NGOs namely 'Care Bangladesh' and 'HIV/AIDS project under Sylhet Samaj Kallayan Sangshta (SSKS)' in Sylhet city. The NGO Outreach Workers (sex workers employed under HIV/AIDS project for providing condom in different spots of the city) introduced one of the researchers to some of the study participants who subsequently helped the researcher to meet other prostitutes, which may be described as adopting snowball sampling to identify the respondents. In addition, the NGO workers helped the researcher to meet some respondents in their service center where the prostitutes generally visit to receive services. Thus, the interviews were conducted at places identified as convenient by each respondent. In addition, some interviews were conducted at Railway station, Court point near Bondor Bazar, and Uposhohor (suburb) of the city.

Collected data were edited properly, read line by line for coding and then concepts were developed. The concepts were grouped into different categories and all the categories were brought into different subthemes through which the experiences of the participants had been analyzed. Moreover, relevant data were converted into quantitative form and has been used in tabular form.

\section{Ethical Issues}

One of the researchers with the help of the NGO workers and NGO Outreach Workers developed effective and trusting relationship with the selected prostitutes to ensure 
their participation and co-operation for collecting data. After introduction with the participants, the researcher explained the purposes of the study and sought permission for asking some sensitive, private and confidential questions relating to her profession during her convenient time at her convenient place to ensure her consent for the interview. The consent was received through mutual discussion and understanding which developed trustworthy relationship between the researcher and the participant, and that was in fact instrumental for collecting relevant data from them.

Before each interview, the participants were requested to participate in the interview voluntarily. Since most of the participants were illiterate and were disinterested to sign a consent form due to cultural norm, the researcher read it out and thereby obtained their oral consent before each interview. Each participant was informed that she had the freedom to answer or not to answer any question, or she could withdraw herself from the interview whenever she intended. In addition, all the participants were assured of maintaining privacy of the data and their identities. Therefore, the researchers used pseudonym to hide the identity of the respondents.

\section{Limitations}

In some cases, it was not possible for the researcher to meet some of the prostitutes for second time for collecting additional data and for receiving further explanation of few data that were given earlier. In the city of Sylhet, the prostitutes generally work on the streets, in different residential hotels and residence of the clients as there is no established brothel in the city. Some of them are involved in their profession under the strict control and monitoring of the brokers and therefore they did not have freedom to speak out with the researcher. Therefore, the researcher did not have the opportunity to meet these prostitutes. Moreover, the researcher had no chance to meet the prostitutes coming from other districts for only hotel-based sex trade, who usually leave the city after a few days of stay under the management of hotel authorities. These prostitutes are generally mobile as they move from one city to another, depending on the demands of the profession. It may therefore be said that the findings of the study do not represent the each category of prostitutes working in the city.

\section{Results}

The prostituted women and girls migrated from rural areas with or without their relatives. After a series of abhorrent incidents, these girls and women had no other alternatives but to embrace prostitution as their profession. Initially, these women and girls were almost unfamiliar and naïve about the profession. However, with continued motivations by senior prostitutes, brokers and (or) pimps they decided to accept prostitution as their means of livelihood, and more so when they compared to the pains, advantages and disadvantages of other available works outside prostitution. Findings of this study indicate that a number of push and (or) pull factors comprising different socioeconomic and psychological determinants force a woman or a girl to become prostitute. Nevertheless, once she is involved in this profession, she is encircled or entrapped by the shackle of push and pull factors and gradually loses all the exit routes to leave prostitution (Figure 1).

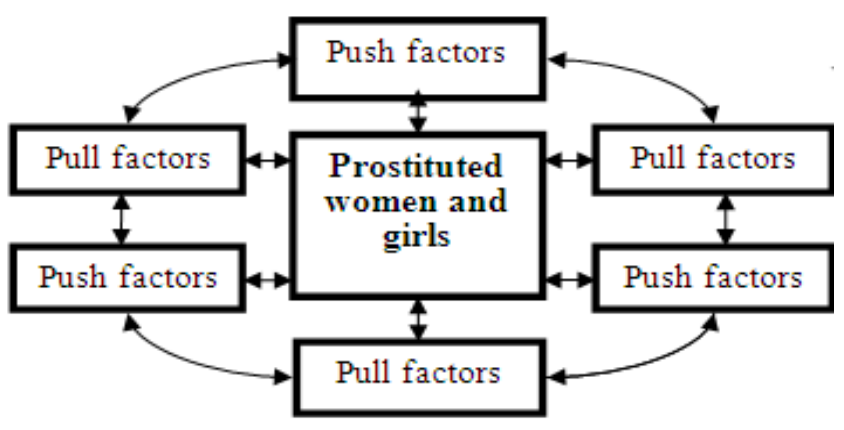

Figure 1. Push and pull factors of prostitution

Push factors identified: The findings of this research identify a number of push factors responsible for pushing women into prostitution. These are: financial crisis, poverty, economic insecurity, that is, death of the earning members and (or) guardians, illiteracy or lack of skills for better employment opportunities, sexual harassment at work place, broken conjugal relationship - desertion, divorce, deception, fraudulence by lover(s), husband(s), cutting off relationship with the family, sexual abuse, physical torture, denial of social justice, social exclusion and alienation, intense feeling of committed sin or guilty feelings, and non-availability of social security programs.

Table1. Major causes for entry into prostitution

\begin{tabular}{|c|c|c|}
\hline Causes & Frequency & Percentage \\
\hline $\begin{array}{c}\text { Financial crisis or demand of more } \\
\text { money }\end{array}$ & 10 & 18.87 \\
\hline Failed to manage a suitable work & 2 & 3.77 \\
\hline Death of husbands/parents & 6 & 11.32 \\
\hline Fraudulence of the lover/husband & 11 & 20.75 \\
\hline $\begin{array}{c}\text { Forced to be a prostitute after being } \\
\text { deserted by the lover }\end{array}$ & 3 & 5.66 \\
\hline $\begin{array}{c}\text { Deserted or divorced by husband } \\
\text { Husband's polygamy, and his } \\
\text { physical and verbal abuse }\end{array}$ & 3 & 13.21 \\
\hline $\begin{array}{c}\text { Physical abuse of relatives (step } \\
\text { mother, step brother, parents) }\end{array}$ & 3 & 5.66 \\
\hline Sexual abuse at work place & 8 & 15.09 \\
\hline Total & 53 & $100 \%$ \\
\hline
\end{tabular}


Pull factors identified: At the same time, it is apparent from the research findings that there are a number of pull factors, which attracted these women and girls to accept prostitution. These are income opportunity, intended to earn more and easy money, sexual enjoyment and freedom of life, well adapted with a different lifestyle, attraction toward drugs, and brokers' motivations.

Findings indicate that multifarious psychosocial and economic factors are responsible for initial engagement of women into prostitution (Table-1).

\section{Poverty/Financial Crisis or Demand of more Money}

Female prostitution in Bangladesh is fundamentally interrelated with poverty or financial crisis and lack of access to suitable works. Increasing rural poverty forces young girls and women to migrate to the cities in search of work where they are sometimes misled by the brokers through giving false promises, and subsequently are entrapped into prostitution. Financial vulnerability and the ambition of earning more money motivate some women to ignore the traditional values of being chaste. It was estimated that the prostitutes could earn US $\$ 25$ to 250 or more per month. After securing financial stability through sex work, a woman or a girl does not intend to leave the profession any more. Nilufa (29), who live in a slum and have the diverse experience of sexual abuse and financial vulnerability, explained....

I lost my mother in my childhood and worked as a domestic help to bear the expenses of my father's treatment. I had to sleep at the corridor of my master's house and wandered from house to house for getting a work. I was sexually harassed and raped on several occasions in my master's house, where often I failed to protect my chastity. After the death of my father, I could not marry due to poverty but had to engage myself into prostitution, as I have the responsibility to take care of my younger sister with my earnings.

\section{Fraudulence and Cheating}

Around $21 \%$ of the prostitutes explained that they were forced into prostitution either by their so-called lover or by husband who pretended to be genuine, but in fact lured them into the profession. They either sold the women to the brokers or forcefully engaged them into prostitution. Some of the married prostitutes alleged that their husband(s) themselves brought them into this profession forcefully despite their strong resistance. They did not have any prior idea about prostitution before joining it. Kumkum (20), shares her painful story.

I was born in a Garo (an aboriginal community) family in Rangamati district. I had an affair with a Muslim boy, and eloped with him. I was completely unaware of horrific intentions of my husband who was a broker of prostitutes. He brought me to Sylhet and forcefully engaged me into prostitution. Since I had broken all relationships with my parents, I had no way to return and finally decided to accept prostitution as my profession.

Some of the respondents (5.66\%) eloped with their lovers and came to Sylhet city. After a few days, lovers suddenly left the girls keeping them vulnerable. Since the incident of eloping tarnishes the family honor and prestige, and the eloped girls are also stigmatized in Bangladeshi culture; they could not return to their fathers' home any more. Having no other alternatives to earn a decent living they were forced to take up prostitution as Koli (21), abandoned by her lover, explained.

I fell in love and eloped. After coming to Sylhet, my fiancée left me immediately. I did not know about the city and became helpless. I had no way to return to my home since that incident of eloping shocked my family and relatives. I was ashamed of that incident and became very upset. In the meantime, a broker encouraged me to be engaged with prostitution and I agreed.

\section{Social Exclusion and Alienation}

After being involved in prostitution, women generally break ties with their relatives and families to hide their profession from them. They maintain neither intimacy nor do they communicate with their parents or relatives. This alienation forces them to carry on their profession. The prostitutes live in different slums, at railway platforms, in rented buildings at residential areas, at open space and temporary houses built alongside railway tracks. Most of them live alone but some live with their family members or fellow prostitutes concealing their professional identity to the neighbors. They remain busy with their profession, and avoid all social association - that is, they hardly interact with the mainstream people, and do not even intend to have warm relationship with the neighbors. Selina (27) shared.

\begin{abstract}
Neither my parents nor relatives know anything about my source of income. I avoid visiting my parents and also do not maintain any connection with the relatives. Even, I do not talk to the neighbors. It is sad that the community where I was born and brought up simply ousts me, treating as a sinner. People of mainstream society hate and abuse me, often call me veshya. I, therefore, almost remain alienated and have completely been excluded from the society.
\end{abstract}

\section{Divorce and Desertion}

Interestingly, our research finds that the number of married prostitutes $(32.08 \%)$ is higher than that of the unmarried ones $(26.42 \%)$. The rest are deserted $(24.53 \%)$, divorcees (11.32\%), and widows (5.66\%). Considering the family poverty, some married or ever-married women found no alternative other than taking prostitution as their profession. Furthermore, lower status of divorcee women and deprivation from their property push them into the situation of vulnerability. Nasima (25), a divorcee, shared.

I lost both of my parents at the age of 14 , and my stepmother did not help me to continue my study. After a few years, I got 
married. Since I could not give birth to children, my husband deserted me. My stepmother and stepbrothers did not let me live with them. Even, my cousin and uncle forcefully took the possession of all of our land property, depriving me from my part of the land. I became very helpless and therefore had to be engaged with prostitution for mere survival.

\section{Attraction of Sexual Pleasure}

Sexual pleasure seems to have attracted some of the prostitutes to carry on their profession, having little possibility of being rehabilitated through sustained marriage. Findings show that $40 \%$ of the prostitutes always enjoy sexual activities with strangers, and the rest (60\%) hardly enjoy. Sokhina (29) speaks out....

I have to have sexual intercourse with different people. It is my livelihood. Even, sometimes I engage myself with sexual activities with strangers despite myself being reluctant. In that case, I do not extract any pleasure from sexual acts. I know that my clients only use my body for their sexual pleasure. I, therefore, do not bear any affection for my clients. Sexual activity with the clients is not always boring to me as I am a divorcee and there is no recognized way open for me for sexual enjoyment.

\section{Domestic Violence}

Our study goes on to show that $5.66 \%$ women (divorcees, deserted and even married women) who went through the repeated experience of severe physical abuse by husbands, gave up their conjugal relations and rather accepted to enter into prostitution. Moni (29) shared her pains.

My husband was a gambler and beat me mercilessly. The intolerable torture made me dissolve my relationship with him. Afterwards, I came to Sylhet and got a job in a restaurant. The owner of that restaurant harassed me sexually, forcing me to leave that job. Then I had to involve myself into prostitution.

\section{Sexual Abuse}

Sexually abused women hardly get justice from the power structure existing in the male-dominated society. They are often blamed for being sexually abused, and the family tries to hide the facts of abuse to preserve family honor and prestige. Nasrin (23) shared her experiences.

Once I was raped by one of my classmates while studying at high school, and villagers came to know about it. I was deprived of justice from the locally arranged salish (arbitrations). Meanwhile, I passed the Secondary School Certificate examination, and my family received many offers of my marriage. However, nobody wanted to marry me after knowing the incident of rape. My parents became very upset and blamed me repeatedly for my bad luck. I was very angry, and came to Sylhet leaving my parents. Here I have learnt how to earn money by selling sex.

After being raped or sexually abused repeatedly either by owners, officers, co-workers or masters of a house, some women $(15.09 \%)$ became exasperated with the sexual attitude of the males, and thereby left the socially approved way of earning livelihood, refrained themselves from societal and religious values, changed their ideology, beliefs and social norms, and ultimately accepted prostitution as a profession. Popi (18) told.

My parents were very poor, because of which I migrated to Sylhet in search of work. At first, I worked as a domestic help. Not only the master of that house raped me several times, but also his son tried to have sex. I had similar experiences while working as domestic help in few other households. At last, my mind has changed drastically, and I decided to accept prostitution as a means of my livelihood.

\section{Poor Educational Background and Lack of Skills}

Rural women with low educational status and lack of skill in any trade migrated to Sylhet, and gradually forced themselves into prostitution after finding no other alternative way of earning. The study shows that approximately $67.92 \%$ of the prostitutes are illiterate, $3.77 \%$ can sign their name, $18.87 \%$ can just read and write and the rest $9.44 \%$ have secondary level of education. After migrating to an unknown city, they were misled by different individuals and ended up into prostitution. Now being into this profession of easy money, they no more intend to quit, as they are unsure of getting a socially recognized work considering their poor educational backgrounds and lack of skills. Moymona (33) expressed her helplessness....

I never went to school. After the death of my husband, I had to work as a domestic help in different households, where I often experienced sexual abuse. Afterwards, I decided not to work as domestic help and started searching for a job. But unfortunately I got no job since I neither had education nor did I have anybody who could have helped me to manage a job for me. I was completely helpless and incidentally a broker suggested me to engage with prostitution to earn money. I had to do it for my survival. Now, I cannot think of leaving prostitution as I do not have any alternative to earn my livelihood.

\section{Motivation of the Brokers}

Pimps and brokers have created a strong network for bringing women and girls into prostitution, especially those who either migrate or live in vulnerable situations. The brokers exploit and motivate these vulnerable women and girls to accept prostitution as an easy way of earning money. Finding no other better alternatives some women and girls decide to enter into this profession. Sometimes a broker approaches a girl as being a lover and brings her into prostitution in a deceptive way. The brokers also motivate some husbands to compel their wife for selling sex. Rupali (35) revealed....

I divorced my husband as he was a drug addict, and we had 
continuous conjugal conflicts. Later, I went to Narayanganj and started working in a readymade garment factory for many years. The supervisor of that factory lured me to have sex. I left that factory and moved to Sylhet when everyone came to know about our illicit relationship. Here, a broker motivated me to sell sex, and now I have become a full-fledged prostitute.

\section{Psychological Factors and Drug Addiction}

As stated above in the section social exclusion and alienation, all the prostitutes under this study lead a socially isolated life. This feeling of isolation seems to be clearly inevitable for them and they will have to bear the pains of isolation throughout their life for entering into this profession. Furthermore, the respondents strongly believe that the society itself does not accept a prostitute as a normal human being, rejects her self-respect and dignity, and frequently label her as a bad woman, very harmful for the people living in the community. Such societal rejection ultimately forces the prostitute to remain alienated and isolated. The findings of the study show that $30.18 \%$ respondents have a feeling of being socially neglected and approximately $45 \%$ respondents have a feeling of being inferior, and always treat themselves as bad, worse, unchaste and sinner. A considerable number of respondents (54.71\%) have developed a strong feeling of being guilty from religious point of view for involving themselves into such a profession.

The study participants are frequently found living with the sense of anxiety since they are always scared of the law enforcing agencies and the anti-socials who try to exploit and even torture them. They always remain scared of the community for fear of being caught especially during the time they need to get involved into the profession. This is because if they are caught they will face torture and abuse not only from the police but also from the public $-38 \%$ of the respondents had the experience of going to the jail several times who had gone through severe police torture after being caught. Multiple types of anxiety usually lead the respondents to be always in stressful situation; they remain under acute stress when they fail to find clients, which in turn create barriers to earning their livelihood. Around $28 \%$ of the respondents have expressed their stressful situation unbearable as they struggle hard to overcome. A few respondents (7.54\%) have described their life as risky one since they are being intimidated from different corners for their profession, which is socially and religiously prohibited. This research also finds that frustration has engulfed all the prostitutes as they are socially excluded to lead a life, which is full of uncertainty with the lack of futuristic hope and aspiration.

After an initial entry into prostitution, a woman or a girl often becomes associated with different kinds of delinquents and clients who are mostly drug addicted and gradually entrap her into this profession, forcing her to remain drunk, especially during the time of dealing with the clients. Drug addiction also influences the prostitutes to lead a distinctive pattern of life causing them to stick to prostitution. Around $47 \%$ of the study participants have developed the habit of smoking regularly, and taking different types of drugs like hemp, alcohol, heroin, etc.

\section{Barriers toward Leaving Prostitution}

From the above findings, it is clear that both social rejection and stigma either discourage the prostitutes to leave or force them to continue their profession. Most of them do not rely on the government rehabilitation program for prostitutes, simply for the fear of being socially rejected, leading them to remain in prostitution. Nevertheless, our study shows that around $86.79 \%$ prostitutes intend to leave prostitution if they are provided with proper job. However, the rest simply do not want to leave the profession. All the prostituted women excepting two under the study apprehended some problems which might affect them in case of leaving the profession (Table-2).

Table 2. Problems apprehended in case of leaving prostitution

\begin{tabular}{|c|c|c|}
\hline $\begin{array}{c}\text { Nature of problems } \\
\text { apprehended* }\end{array}$ & $\begin{array}{c}\text { Frequency } \\
(\mathrm{n}=53)\end{array}$ & Percentage \\
\hline $\begin{array}{c}\text { No opportunity in fulfilling } \\
\text { sexual needs }\end{array}$ & 6 & 11.32 \\
\hline Income decrease & 33 & 62.26 \\
\hline Social rejection & 12 & 22.64 \\
\hline Adjustment problems & 4 & 7.54 \\
\hline Husband's resistance & 12 & 22.64 \\
\hline Possibility of facing starvation & 3 & 5.66 \\
\hline No opportunity of getting work & 5 & 9.43 \\
\hline No problem & 2 & 3.77 \\
\hline
\end{tabular}

* Multiple answers

\section{Discussions}

Researchers have generally agreed that causes of prostitution cannot be explained by a single factor. The entry into prostitution and its continuation in sex industry results from the accumulation of multiple interdependent personal and contextual factors (Dalla, 2002; Giddens, 2001). These factors do not exist in the same form or same degree for all women who prostitute themselves. In reality, the causes of prostitution differ from one woman to another. In the beginning, some push factors influence a woman to enter into prostitution, and once she internalizes the identity of a prostitute, as described by Williamson and Folaron (2003), her conventional relationships become weaker, and she can no more think of living in conventional life. In these circumstances, the pull factors attract her to continue and the 
push factors force her not to leave prostitution simultaneously. Consequently, the pull and push factors entangle her through interrelationships between and among them resulting in forming the shackle of multifarious factors which indeed confine the prostituted women and girls into prostitution.

The findings from this research have mostly identified poverty as the dominating factor that has pushed the women into prostitution. Poverty or financial crisis along with unemployment and underemployment have also been found as the root causes of prostitution in many other studies (Chattopadhyay et al., 1994; Islam, 1994; Karandikar et al., 2011; Monroe, 2005; Rahman, 1999, 2001; Williamson \& Folaron, 2003). Economic theories equally explain poverty and women having less control over material resources as the causal factors for female prostitution (Flowers, 2001).

According to the findings of the study, prostituted women and girls went through a long way of sexual abuse by different individuals at different places, particularly at workplace, which was instrumental for them to decide to embrace prostitution. They were the victims of injustice meted out by the male dominated power structure. Even, the family to which they belonged kept the incidents of sexual abuse hidden to save and preserve the family honor and prestige. Khan (2005) also shows that female domestic workers are often physically and (or) sexually abused in Bangladesh. Theories of physical and sexual abuse substantiate this finding, as these factors are considered as key factors responsible for women and girls to enter into prostitution (Flowers, 1998; Karandikar et al., 2011; Kramer \& Berg, 2003; Ross, et al., 2004; Silbert \& Pines, 1982; Simons \& Whitbeck, 1991; Surratt et al., 2004; Tyler, Hoyt, \& Whitbeck, 2000). Violence against women in the form of physical, sexual or verbal is widespread throughout Bangladesh and most of the spousal conflicts turn the form of physical abuse to women (Bhuiya et al., 2003; Dalal et al., 2009; Khan, 2005; Sambisa et al., 2010). Along with domestic violence divorce, separation, and desertion of women also play vital roles to move them into prostitution - this finding of our research bears resonance to a number of other studies (Chattopadhyay et al. 1994; Karandikar et al., 2011; Rahman, 1999).

The patriarchal sexual ideology, sexually objectification of women, violence, gender based discrimination and inequality have been identified in this study as the causal factors for prostitution, which have also been substantiated by feminist theories of prostitution (Selfe \& Burke, 2001).

The study shows that fraudulence and cheating by husbands, lovers and (or) brokers have made some women and girls to enter into this profession. This finding of this research supports a numbers of previous studies (Rahman, 1999, 2001; Islam, 1994; Tahmina \& Moral, 2004). No prostituted women among the respondents had prior idea about sex work but they had to learn it from others like brokers, senior and fellow prostitutes, and that can be well explained by differential association theory of Sutherland
(Flowers, 2001; Pandey, 1994).

Theories like labeling theory (Flowers, 2001; Schaefer, 2007), Merton's theory of deviance (Giddens, 2001; Schaefer, 2007) have explained that deviants are stigmatized and labeled as bad human beings which force them to remain in their deviant activities. Since prostitutes are greatly labeled as fallen or unchaste (Hammond, 2008; Kole, 2009; Tahmina \& Moral, 2004), they feel forced to be marooned into prostitution, which largely substantiate the findings of the present study.

Prostitutes under this study have been identified as having low educational status and possessing no skills in any trade that lead them into this profession, and discourage them to leave the profession. Other studies (Chattopadhyay et al., 1994; Kramer and Berg, 2003; Rahman, 2001) have also underlined these factors as causing prostitution.

Like other studies (Farley \& Barkan, 1998; Flowers, 2001; Ross, et al., 2004; Williamson \& Folaron, 2003; Young et al., 2000), the present research also finds that prostitutes suffer from alienation, isolation, frustration and depression, and anxiety. However, in our research no one was found suffering from major psychological disorders like dissociative, posttraumatic, mood disorder etc., which were identified with prostitutes under different studies (Farley \& Barkan, 1998; Ross, et al., 2004). Nevertheless, this research shows that majority of the participants have admitted that they remain addicted with different types of drugs that generally keep them hypnotized with the profession. It is noteworthy that none of the participants was a drug addict before entering into prostitution.

\section{Implications for Social Work}

Social work is a profession that often tries to address the situation of vulnerabilities that affect most people. Therefore, social workers do have the opportunity to identify different vulnerable situations because of which some women and girls feel forced to decide to enter into prostitution. For this, they need to work with community to educate people with proper information so that women and girls can be protected from being cheated or abused or abducted. It is a kind of preventive measure, which is essential for protecting the vulnerable girls from the hands of deviants and wicked people. Social workers can also work with the prostitutes to make them cautious about the danger of being infected with HIV/AIDS, and prostitutes suffering from HIV/AIDS/STD or any other sexual diseases may be helped by social workers to encourage them to visit doctors or they can refer them or even take them to the appropriate doctors, clinic or hospitals for treatment. Prostitutes are mostly found frustrated and anxious about their future life, and the social workers can effectively reduce the level of their frustration and anxiety by providing them with counseling which may help them to bring their confidence back and feel self-reliant. Apart from that, social workers can perform advocacy in favor of the 
prostitutes with different government and non-government agencies for their effective rehabilitations. They can even arrange and help the prostitutes involve themselves in different income generating activities after taking training on different trades that will again help them to come out of the profession if they intend to.

\section{Conclusions}

The prostituted women are not obviously prostitutes by birth; rather the male-dominated society throws them into this unpleasant profession. The findings of this research thus unveil that women and girls enter into this profession either by choice or by force, or they are simply cheated and forced into it. It may therefore be concluded that not a single factor but a number of socioeconomic and psychological factors entrap them into this profession. Notwithstanding, our findings also suggest that no prostitute joined the profession on their own will. Each of them became a victim of a particular situation that pushed them into it. Findings indicate that prostitution for women is obviously a vicious circle where - if someone enters she hardly finds the exit route. Even, if the exit route is somehow ensured the society does not come forward to accept the prostituted women as its member. The very attitude of the people of mainstream society is fully negative towards the prostitutes, and therefore, the practice of social work seems to be relevant and effective in order to change the outlook of the people, and it can also ensure different services for the prostitutes according to their needs and problems. The policy makers need to formulate innovative policies, especially for those who intend to be rehabilitated after leaving prostitution, so that effective measures may be undertaken to bring the prostituted women back to normal social life.

\section{Acknowledgements}

The authors are grateful to the employees of HIV/AIDS/STD prevention project undertaken by SSKS (an NGO working in Sylhet city, Bangladesh), the Service Promotion Officer and Outreach Workers of the same project for extending their co-operation during data collection. The authors are really indebted and grateful to all the prostitutes for participating in the project in Sylhet city.

\section{REFERENCES}

Aziz, K. M. A. (2003). Sex Worker. In S. Islam (Ed.), Banglapedia- National Encyclopedia of Bangladesh. Retrieved from http://www.banglapedia.org/HT/S_0256.htm (accessed January 11, 2014)

Bhuiya, A., Sharmin, T., \& Hanifi, S. M. A. (2003). Nature of domestic violence against women in a rural area of Bangladesh: Implication for preventive interventions. Journal of Health
Population and Nutrition, 21(1), 48-54.

Biraj, A. (2012, March 19). Bangladesh's "teenage" brothels hold dark steroid secret. REUTERS. Retrieved from http://www.reuters.com/article/2012/03/19/us-bangladesh-prostitut ion-idUSBRE82I02A20120319 (accessed August 28, 2013)

Bishop, E. (2006). Arab Gulf. In M. H. Ditmore (Ed.), Encyclopedia of prostitution and sex work (Vol. 1, pp. 40-43). London: Greenwood Press.

Campo, J. E. (2009). Encyclopedia of Islam. New York NY: Facts on File.

Chattopadhyay, M., Bandyopadhyay, S., \& Duttagupta, C. (1994). Biosocial factors influencing women to become prostitutes in India. Social Biology, 41(3-4), 252-259.

Dalla, R. L. (2002). Night moves: A qualitative investigation of street-level sex work. Psychology of Women Quarterly, 26(1), 63-73. doi: 10.1111/1471-6402.00044

Dalal, K., Rahman, F., \& Jansson, B. (2009). Wife abuse in rural Bangladesh. Journal of Biosocial Science, 41, 561-573. doi:10.1017/S0021932009990046

Ditmore, M. H. (2006). Introduction. In M. H. Ditmore (Ed.), Encyclopedia of prostitution and sex work (pp. xxv-xxxvii). London: Greenwood Press.

Dummett, M. (2010, May 30). Bangladesh's dark brothel steroid secret. BBC News South Asia. Retrieved from http://www.bbc.co.uk/news/10173115 (accessed August 28, 2013)

Farley, M., \& Barkan, H. (1998). Prostitution, violence, and posttraumatic stress disorder. Women and Health, 27(3), 37-49.

Flowers, R. B. (1998). The prostitution of women and girls. London: McFarland and Company, Inc., Publishers.

Flowers, R. B. (2001). Runway kids and teenage prostitution: America's lost, abandoned, and sexually exploited children. Westport: Praeger Publisher.

Giddens, A. (2001). Sociology. Cambridge: Polity Press.

Hammond, C. (2008, January 17). Grim life for Bangladeshi prostitutes. BBC News, Bangladesh, Retrieved from http://news.bbc.co.uk/2/hi/programmes/from our_own correspon dent/7191283.stm (accessed August 28, 2013)

Islam, M. S. (1994). Prostitution: causes and remedies. Dhaka: Nirjhor Publications (In Bangla).

Karandikar, S., Gezinski, L. B., \& Meshelemiah, J. C. A. (2011). A qualitative examination of women involved in prostitution in Mumbai, India: The role of family and acquaintances. International Social Work. doi: 10.1177/0020872811425804

Khan, F. C. (2005). Gender violence and development discourse in Bangladesh. International Social Science Journal, 57(184), 219-230. doi: 10.1111/j.1468- 2451.2005.546.x

Kole, S. K. (2009). From "veshyas" to "entertainment workers": Evolving discourses of bodies, rights, and prostitution in India. Asian Politics \& Policy, 1(2), 255-281. doi: 10.1111/j.1943-0787.2009.01115.x

Kornblum, W. (2008). Sociology in a changing world, Belmont, CA: Thomson Higher Education.

Kramer, L. A., \& Berg, E. C. (2003). A survival analysis of timing 
of entry into prostitution: The differential impact of race, educational level, and childhood/adolescent risk factors. Sociological Inquiry, 73(4), 511-528. doi: 10.1111/1475-682X.00069

Monroe, J. (2005). Women in street prostitution: The result of poverty and the brunt of inequity. Journal of Poverty, 9(3), 69-88. doi: 10.1300/J134v09n03_04

Mukherjea, A. (2006). South Asia. In M. H. Ditmore (Ed.), Encyclopedia of prostitution and sex work (Vol. 2, pp. 449-452). London: Greenwood Press.

Norris, J. (2006). Religion. In M. H. Ditmore (Ed.), Encyclopedia of prostitution and sex work (Vol. 2, pp. 388-393). London: Greenwood Press.

Pandey, R. (1994). Social problems of contemporary India. New Delhi: Ashish Publishing House.

Prostitution. (2014). In Encyclopaedia Britannica. Retrieved from http://www.britannica.com/EBchecked/topic/479546/p rostitution (accessed January 11, 2014)

Rahman, M. H. (1999). Social history and development thinking. Dhaka: Gatidhara (In Bangla).

Rahman, M. H. (2001). Social work and social development. Dhaka: Gatidhara.

Ross, C. A., Farley, M., \& Schwartz, H. L. (2004). Dissociation among women in prostitution. Journal of Trauma Practice, 2(3-4), 199-212.

Sambisa, W., Angeles, G., Lance, P. M., Naved, R. T., \& Curtis, S. L. (2010). Physical and sexual abuse of wives in urban Bangladesh: husbands' reports. Studies in Family Planning, 41(3), 165-178. doi: $10.1111 / \mathrm{j} .1728-4465.2010 .00241 . \mathrm{x}$

Sanders, T., O’Neill, M., \& Pitcher, J. (2009). Prostitution: Sex Work, Policy and Politics. New Delhi: Sage.

Schaefer, R. T. (2007). Sociology. Boston: McGraw Hill.
Schuler, S. R., \& Islam, F. (2008). Women's acceptance of intimate partner violence within marriage in rural Bangladesh. Studies in Family Planning, 39(1), 49-58. Retrieved from http://www.jstor.org/stable/20454436

Selfe, D., \& Burke, V. (2001). Perspectives on sex, crime and society. London: Cavendish Publishing Ltd.

Silbert, M. H., \& Pines, A. M. (1982). Victimization of street prostitutes. Victimology: An InternationalJournal,7, 122-133.

Simons, R. L., \& Whitbeck, L. B. (1991). Sexual abuse as a precursor to prostitution and victimization among adolescent and adult homeless women. Journal of Family Issues, 12(3), 361-379. doi: $10.1177 / 019251391012003007$

Surratt, H. L., Inciardi, J. A., Kurtz, S. P., \& Kiley, M. C. (2004). Sex work and drug use in a subculture of violence. Crime and Delinquency, 50(1), 43-59. doi: 10.1177/0011128703258875

Tahmina, Q. A., \& Moral, S. (2004). Sex-workers in Bangladesh: Livelihood at what price? Dhaka: Society for Environment and Human Development (SEHD).

Tyler, K. A., Hoyt, D. R., \& Whitbeck, L. B. (2000). The effects of early sexual abuse on later sexual victimization among female homeless and runaway adolescents. Sociology Department, Faculty Publications, Paper 33. Retrieved from http://digitalcommons.unl.edu/sociologyfacpub/33

Valandra (2007). Reclaiming their lives and breaking free: An Afrocentric approach to recovery from prostitution. Affilia: Journal of Women and Social Work, 22 (2), 195-208. doi: $10.1177 / 0886109907299052$

Williamson, C., \& Folaron, G. (2003). Understanding the experiences of street level prostitutes. Qualitative Social Work, 2(3), 271-287. doi: 10.1177/14733250030023004

Young, A. M., Boyd, C., \& Hubbell, A. (2000). Prostitution, drug use, and coping with psychological distress. Journal of Drug Issues, 30(4), 789-800. 